Reprinted from the Journal of Envirommenal Qualiny

Volume 20 no 6 , Nov -Dec 2000 Copyright 02000 , ASA, CSSA, SSSA

677 South Segoe Rd., Madison, W1 53711 USA

\title{
Rainfastening of Bifenthrin to Cotton Leaves with Selected Adjuvants
}

\author{
J. E. Mulrooney* and C. D. Elmore
}

\begin{abstract}
There are thousands of adjuvants on the market, yet little is known about their effects on the activity of insecticides on plant surfaces. The effects of 11 selected adjuvants on the rainfastness and retention of bifenthrin $([1 \alpha, 3 \alpha-(Z)-( \pm)-(2$ methyl[1,1'-biphenyl]-3-yl) methyl 3-(2-chloro-3,3,3-trifluoro-1-propenyl)-2,2-dimethylcyclopropanecarboxylate) on cotton (Gossypium hirsutum L.) leaves were investigated. In addition, the effect of the adjuvant Bond on the efficacy of bifenthrin and a Bacillus thuringiensis (Berliner) formulation was determined. Bifenthrin mixed with each adjuvant was applied to greenhouse grown cotton plants using a spray chamber. Simulated rainfall of $13 \mathrm{~mm}$ was then applied to treated cotton plants at 0.25 , 1 , and $4 \mathrm{~h}$ after treatment. Bond and Agrimax-3 were the only adjuvants to significantly increase the rainfastness of bifenthrin on cotton leaves. Agri-Dex, Soy-Dex, and Dyne-Amic significantly decreased the rainfastness of bifenthrin. In tests conducted with an immersion cell apparatus, Orchex 796 resulted in twice the retention of Agri-Dex, the next highest retained adjuvant. Both petroleum and vegetable oils enhanced retention of bifenthrin on the leaf surface. Bond mixed with bifenthrin and a $B$. thuringiensis formulation did not reduce the activity of these insecticides against tobacco budworm (Heliothis virescens) and soybean looper (Pseudoplusia includens) larvae. Retention on the leaf may be related to spread and to the degree of binding of the insecticide to the surface by properties of the adjuvant. Yet, the properties of Agri-Dex that enhanced the retention of bifenthrin to the cotton leaf decreased its rainfastmess.
\end{abstract}

$\mathrm{S}^{\mathrm{n}}$ RAY adjuvants may enhance pesticide activity and minimize the effects of environmental factors on pesticide application and decomposition. Thousands of adjuvants are now on the market. Foy (1993), in a survey of product labels from 485 formulations of crop protection chemicals for use in 1992 , found that $49 \%$ of the formulations recommended adjuvant use, $5 \%$ recommended no adjuvant, and the remaining $46 \%$ did not mention adjuvant use. Adjuvants were recommended with $71 \%$ of the herbicide formulations and with $30 \%$ of the other classes of crop protection chemicals, while $14 \%$ of the other classes of crop protection chemicals did not recommend an adjuvant.

The greatest reduction of pesticide efficacy results from environmental factors. While sunlight gradually decomposes pesticides on the leaf surface, rainfall has an immediate effect on the adherence of pesticide residues to plant surfaces, especially if a storm occurs shortly after application.

Studies have shown that rainfall amount more greatly

USDA, ARS, Application and Production Technology Research Unit, Stoneville, MS 38776. Received 9 Aug. 1999. *Corresponding author (jmulrooney@ars.usda.gov)

Published in J. Environ. Qual. 29:1863-1866 (2000). affects the washoff of insecticides from cotton plants than does rainfall intensity. However, the effect of elapsed time between insecticide application and rainfall on insecticide washoff from plants varies with insecticide and/or formulation. For example, methyl parathion that is washed from cotton plants decreases exponentially with time after application and linearly with the concentration on the plant (McDowell et al., 1984). In contrast, the fractions of toxaphene and fenvalerate washed from the plants were relatively constant at 10 and $7 \%$, respectively, regardless of time after application and amount on the plants. Pick et al. (1984), using overhead irrigation to simulate rairfall, concluded that endosulfan, cypermethrin, and carbaryl became more resistant to washoff with time after application.

Even low amounts of rain can have drastic effects on insecticide residues. About $63 \%$ of carbaryl on cotton plants $2 \mathrm{~h}$ after application was washed off by $25 \mathrm{~mm}$ of rain; while an additional $76 \mathrm{~mm}$ of rain removed another $35 \%$ of the total (Willis et al., 1988).

Insecticide formulations vary in rainfastness. Washoff studies showed that insecticide resistance to washoff decreased in this order: toxaphene $>$ fenvalerate $=$ permethrin $>$ EPN $>$ methyl parathion (McDowell et al., 1987). About $35 \%$ of the permethrin load on plants $2 h$ after application was washed off by $25 \mathrm{~mm}$ of rain with an additional $76 \mathrm{~mm}$ of rain removing only $11 \%$ more of the total (Willis et al., 1986).

The greatest portion of insecticides used for cotton insect control in the southern USA is applied during July, August, and September, which are months with frequent high-intensity thunderstorms. Adjuvants that provide some rainfastness of insecticides could be costeffective in areas of the country that receive abundant rainfall, especially when insect populations are at an economic threshold and larvae are exceeding controllable size.

This research determined the effectiveness of several available adjuvants to rainfasten a pyrethroid insecticide to cotton leaves. Bioassays were conducted to detect any antagonism between rainfastening ability and insecticide activity. In addition, the retention of these insecticide-adjuvant mixtures on the surface of cotton leaves was measured using a recently designed immersion cell apparatus.

\section{MATERIALS AND METHODS}

\section{Rainfastness Test}

Eleven adjuvants (Table 1) representing spreader-stickers (an adjuvant that has the properties of both a spreader and a sticker), crop oil concentrates, and nonionic surfactants were 
Table 1. Adjuvants used in rainfastness tests of bifenthrin applied to greenhouse cotton at Stoneville, MS.

\begin{tabular}{|c|c|c|c|c|}
\hline Adjuvant & $\%(v / v)$ & Manufacturer & Description & Constituents \\
\hline Agri-Dex & 2.0 & Helena Chemical, Memphis, TN & Crop oil concentrate & $\begin{array}{l}\text { paraffin base petroleum oil, polyol fatty acid esters, } \\
\text { polyethoxylated dervatives }\end{array}$ \\
\hline Agrimax-3 & 0.25 & ISP Technologies, Wayne, NJ & $\begin{array}{l}\text { Spreader/sticker/ } \\
\text { penetrant }\end{array}$ & $\begin{array}{l}\text { mixture of alkypyrrolidone solvents and polymers } \\
\text { with anionic surfactant }\end{array}$ \\
\hline Agrimax $3 \mathbf{H}$ & 0.25 & ISP Technologies & $\begin{array}{l}\text { Spreader/sticker/ } \\
\text { penetrant }\end{array}$ & $\begin{array}{l}\text { mixture of alkypyrrolidone solvents and polymers, } \\
\text { anionic surfactant, and heavy aromatic petroleum } \\
\text { solvent }\end{array}$ \\
\hline Bond & 0.25 & Loveland Industries, Greely, $\mathrm{CO}$ & $\begin{array}{l}\text { Sticker/extender/ } \\
\text { deposition agent }\end{array}$ & $\begin{array}{l}\text { synthetic latex }(45 \%) \text { and primary aliphatic oxyaly- } \\
\text { lated alcohol }(10 \%)\end{array}$ \\
\hline Dyne-Amic & 0.5 & Melena Chemical & Nonionic spreader & $\begin{array}{l}\text { methylated vegetable oils with organosilicone } \\
\text { surfactants }\end{array}$ \\
\hline Kinetic & 0.25 & Helena Chemical & $\begin{array}{l}\text { Wetter/spreader/ } \\
\text { penetrant }\end{array}$ & $\begin{array}{l}\text { blend of polyalkyleneoxide modified polydimethylsi- } \\
\text { lonxane and nonionic surfactants }(99 \%)\end{array}$ \\
\hline Penetrator Plus & 0.25 & Helena Chemical & $\begin{array}{l}\text { Nonionic buffer/spreaded } \\
\text { wetter/penetrant }\end{array}$ & $\begin{array}{l}\text { paraffin oil, polyol fatty acid esters, polyethoxylated } \\
\text { esters, and ethoxylated alkyl aryl phosphate esters }\end{array}$ \\
\hline Plyac & 0.25 & Loveland Industries & Nonionic spreater/sticker & $\begin{array}{l}\text { emulsifiable oxidized polyethylene and ethoxylated } \\
\text { phenox alcohol }(28 \%)\end{array}$ \\
\hline Silwet-77 & 0.1 & Loveland Industries & Nonionic spreader & organosilicone copolymers \\
\hline Soy-Dex & 1.0 & Setre Chemical, Memphis, TN & Vegetable oil adjuvant & $\begin{array}{l}\text { vegetable oil }(85 \%) \text {, nonionic blend of alkoxylated } \\
\text { alkylphenols, and fatty acids }(15 \%)\end{array}$ \\
\hline$X-77$ & 0.25 & Loveland Industries & Spreader/activator & $\begin{array}{l}\text { alkylarylpolyoxyethylene, glycols, free fatty acids, } \\
\text { and isopropanol }\end{array}$ \\
\hline
\end{tabular}

tested for rainfastness. The adjuvants were divided into three groups and evaluated in separate tests because of the time required to treat, collect, and process leaf samples and because of constraints inherent in tests with time as a factor.

Adjuvants were mixed with bifenthrin (Capture 2 EC, FMC Corp., Philadelphia, PA) in percentages based on the manufacturers' recommendations. A spray chamber was used to apply treatments to potted cotton plants that had been grown in a greenhouse. Cotton plants had seven to nine nodes at the time of application. Application of $112 \mathrm{~g}$ a.i. $\mathrm{ha}^{-1}$ in a $46.7 \mathrm{~L} \mathrm{ha}^{-1}$ volume was made in a spray chamber (speed, $4.0 \mathrm{~km} \mathrm{~h}^{-1}$; pressure, $255 \mathrm{kPa}$; TX-3 nozzle, Spraying Systems, Wheaton, IL). After application of adjuvant $\times$ bifenthrin treatments, plants were treated with $13 \mathrm{~mm}$ of rain at $0.25,1$, and $4 \mathrm{~h}$ after treatment. The amount of rainfall was determined by rain gauges placed next to plants receiving rainfall. The rain simulator (Bryson, 1987) delivered a pulsating flow of water at 13.7 to $20.6 \mathrm{kPa}$ that closely simulated rainfall.

Before each application of rainfall, a pre-rain sample consisting of a $3.8-\mathrm{cm}^{2}$ leaf disk was cut with a cork borer from one side of the leaf. After the plant received a $12.7 \mathrm{~mm}$ of rain, a post-rain sample $\left(3.8-\mathrm{cm}^{2}\right.$ leaf disk) was taken from the opposite side of the leaf from the pre-rain sample. Three pre-rain and three post-rain samples were taken from each plant.

The pre-rain and post-rain leaf disks from each plant were sealed in separate plastic ziploc bags and refrigerated. Bifenthrin residues were removed from leaf disks by placing them in $10 \mathrm{~mL}$ of ethanol and shaking at $150 \mathrm{rpm}$ for $5 \mathrm{~min}$.

Samples of each spray mixture were taken before and after spraying to accurately determine the concentration of bifenthrin being applied. Sheets $(12.7 \times 12.7 \mathrm{~cm})$ of mylar and alphacellulose were placed horizontally on a ring stand positioned in the center of the spray swath. These samples provided additional determinations of spray deposition. Mylar and alphacellulose sheets were cut into 10 to 12 sections, placed in $300 \mathrm{~mL}$ of ethanol, and shaken at $150 \mathrm{rpm}$ for $30 \mathrm{~min}$. Sample volume was reduced to exactly $10 \mathrm{~mL}$ by roto-evaporation. A 2-mL aliquot was placed in autosampler vials for residue analysis by gas chromatography.

Aliquots $(2 \mathrm{~mL})$ of residue samples were analyzed without cleanup using a Hewlett-Packard (Palo Alto, CA) 5890 gas chromatograph equipped with a $\mathrm{Ni}^{63}$ electron capture detector. A $0.32-\mathrm{mm} \times 25-\mathrm{m}$ methyl silicone column was used. An autoinjector introduced $1-\mu \mathrm{L}$ samples into the inlet. Quantifi- cation was by peak area. Temperatures were: inlet, $280^{\circ} \mathrm{C}$; detector, $320^{\circ} \mathrm{C}$; oven, $160^{\circ} \mathrm{C}$ (initial temperature) and $280^{\circ} \mathrm{C}$ (final temperature), with a $40^{\circ} \mathrm{C} \mathrm{min}^{-1}$ ramp. Helium flow

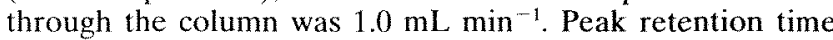
was $11.09 \mathrm{~min}$.

There were three replications of each treatment. Data were expressed as percent retention of bifenthrin on the leaf surface as a result of rainfall (percent retention $=1$ - Ipre-rain deposit - post-rain deposit $\div$ pre-rain deposit] $\times 100$ ).

\section{Retention Test}

The retention of bifenthrin-adjuvant mixtures was tested using an immersion cell apparatus (Carlton, 1996). This apparatus measures the maximum amount of liquid retained by a leaf by covering $10.9 \mathrm{~cm}^{2}$ of the leaf surface with a liquid and then decanting the liquid from the leaf surface. The remaining amount of liquid on the leaf surface represents maximum retention. The immersion cell consists of a bank of four clamp devices that rigidly hold open-ended reservoirs on test leaves. Resilient cylinder-type seals (Carlton, 1992$)(5.08 \mathrm{~cm}$ i.d.) mounted onto the ends of Teflon cell $(3.73 \mathrm{~cm}$ diameter) walls seal the liquid between the wall and the leaf surface

The cell walls and seals were first prewetted with the test formulation to reduce loss of liquid due to retention on these surfaces. The immersion cell was clamped on the upper surface of a cotton leaf. About $3 \mathrm{~mL}$ of test liquid was injected from a 10 -mL burette into each cell. The base holding the four reservoirs was tilted back and forth to insure the surfaces of the leaves were completely covered. Then the bank was tilted $30^{\circ}$ and the liquid was transferred from each cell back into the burette using a small hand pump mounted on the burette. The difference in the initial volume and the remaining volume in the burette was the amount of liquid retained on $10.9 \mathrm{~cm}^{2}$ of the upper leaf surface. There were four replicates of each bifenthrin + adjuvant mixture with four leaves constituting a replicate.

\section{Bioassay}

Two bioassays were conducted to test the effect of a spreader-sticker on the efficacy of two insecticides with different modes of activity. Tobacco budworm larvae, which are fruit feeders, were chosen to bioassay leaves treated with a contact insecticide because larvae are normally poisoned by 
Table 2. Percentage retention $\pm \mathrm{SEM} \dagger$ of bifenthrin + adjuvant residues on cotton leaves after simulated rainfall $(13 \mathrm{~mm})$ apphied af different times after treatment.

\begin{tabular}{|c|c|c|c|}
\hline \multirow[b]{2}{*}{ Treatment } & \multicolumn{3}{|c|}{ Hours after application } \\
\hline & 0.25 & 1 & 4 \\
\hline & & $\begin{array}{r}\% \\
\text { Test } 1 \\
\end{array}$ & \\
\hline $\begin{array}{l}\text { Control } 4 \\
\text { Agrimax-3 } \\
\text { Bond } \\
\text { Silwet } 77 \\
X-77\end{array}$ & $\begin{array}{l}21.8 \pm 1.2 \mathrm{~b} \$ \\
21.1 \pm 2.9 \mathrm{~b} \\
40.7 \pm 0.3 \mathrm{a} \\
14.4 \pm 0.8 \mathrm{c} \\
14.9 \pm 0.8 \mathrm{c}\end{array}$ & $\begin{array}{c}28.0 \pm 2.4 \mathrm{~b} \\
28.4 \pm 2.3 \mathrm{~b} \\
58.9 \pm 5.2 \mathrm{a} \\
19.2 \pm 3.4 \mathrm{bc} \\
11.8 \pm 2.7 \mathrm{c} \\
\text { Test } 2\end{array}$ & $\begin{array}{l}21.8 \pm 10.2 \mathrm{a} \\
32.8 \pm 5.4 \mathrm{a} \\
41.1 \pm 4.5 \mathrm{a} \\
30.5 \pm 7.2 \mathrm{a} \\
18.8 \pm \mathbf{3 . 0 a}\end{array}$ \\
\hline $\begin{array}{l}\text { Control } \\
\text { Kinetic } \\
\text { Agrimax-3H } \\
\text { Penetrator Plus }\end{array}$ & $\begin{array}{l}21.5 \pm 1.1 \mathrm{ab} \\
18.3 \pm 0.3 \mathrm{c} \\
23.1 \pm 0.5 \mathrm{a} \\
19.8 \pm 1.1 \mathrm{bc}\end{array}$ & $\begin{array}{c}39.8 \pm 4.1 \mathrm{a} \\
21.6 \pm 1.8 \mathrm{~b} \\
25.1 \pm 6.2 \mathrm{~b} \\
19.9 \pm 1.1 \mathrm{~b} \\
\text { Test } 3\end{array}$ & $\begin{array}{l}34.3 \pm 5.6 \mathrm{a} \\
22.8 \pm 4.7 \mathrm{a} \\
33.6 \pm 3.2 \mathrm{a} \\
23.9 \pm 4.3 \mathrm{a}\end{array}$ \\
\hline $\begin{array}{l}\text { Control } \\
\text { Agri-Dex } \\
\text { Soy-Dex } \\
\text { Dyme-Amic } \\
\text { Plyac }\end{array}$ & $\begin{aligned} 22.2 & \pm 4.0 \mathrm{~b} \\
10.0 & \pm 1.9 \mathrm{c} \\
11.6 & \pm 0.7 \mathrm{c} \\
6.9 & \pm 2.1 \mathrm{c} \\
33.7 & \pm 3.2 \mathrm{a}\end{aligned}$ & $\begin{aligned} 27.1 & \pm 3.4 \mathrm{a} \\
9.0 & \pm 1.4 \mathrm{c} \\
15.8 & \pm 2.6 \mathrm{hc} \\
10.2 & \pm 3.2 \mathrm{c} \\
18.3 & \pm 1.9 \mathrm{~b}\end{aligned}$ & $\begin{aligned} 26.4 & \pm 0.7 \mathrm{~b} \\
9.9 & \pm 1.6 \mathrm{~d} \\
24.0 & \pm 2.0 \mathrm{bc} \\
16.5 & \pm 3.2 \mathrm{~cd} \\
35.7 & \pm 4.9 \mathrm{a}\end{aligned}$ \\
\hline
\end{tabular}

Standard error of the mean.

Bifenthrin alone (Capture 2EC, FMC Corp., Philadelphia, PA).

$\$$ Means in a column for separate tests followed by the same letter are not significantly different $(P<0.05)$ as determined by PDIFF (SAS Institute 1990).

contact with insecticide residues deposited on the surfaces of cotton plants. Insecticides are rarely deposited at the feeding sites (cotton fruit buds) of tobacco budworm larvae. Soybean looper larvae were chosen to bioassay soybean [Glycine max (L.) Merr.] leaves treated with a stomach insecticide because they are foliage feeders. Soybean leaves were chosen as feeding substrates over cotton because the allelochemical content of cotton is higher and more complex than that of soybean, and less confounding of the effects of the stomach insecticide and adjuvant than would be expected.

The insecticides were bifenthrin, a contact insecticide, and a B. thuringiensis formulation (Dipel ESNT, Abbott Laboratories, Chicago, IL) that must be ingested by larvae. Both insecticides were applied in a $46.7 \mathrm{~L} \mathrm{ha}^{-1}$ volume by ground equipment (John Deere [Moline, IL] 6000 hicycle; speed, $8 \mathrm{~km}$ $\mathrm{h}^{-1}$; pressure, $275 \mathrm{kPa}$; nozzle, TX-8). Bifenthrin at $112 \mathrm{~g}$ a.i. $\mathrm{ha}^{-1}$ was applied to cotton plants in the field while $B$. thuringiensis, at $1.17 \mathrm{~L}$ ha ${ }^{-1}$, was applied to soybean in the field. Treated leaves were collected from plants immediately after the spray had dried and brought into the laboratory for bioassay. To bioassay bifenthrin-treated cotton leaves, 3-d-old tobacco budworm larvae were placed on leaves and allowed to crawl over the surface for $3 \mathrm{~min}$. Then larvae were removed from leaves and placed on an artificial diet for $48 \mathrm{~h}$ at which time mortality was determined. To bioassay $B$. thuringiensistreated soybean leaves, leaf disks $(2.54-\mathrm{cm}$ diam.) were cut from leaves and placed in $35-\mathrm{mL}$ diet cups containing gelled agar. One 3-d-old soybean looper larva was placed in each cup. Mortality was determined after $4 \mathrm{~d}$. Larvae were held at $26^{\circ} \mathrm{C}$ during the test period. Larvae from both species were obtained from colonies maintained at the Southern Insect Management Laboratory, Stoneville, MS.

\section{Data Analysis}

Data from the rainfastness tests were arcsin transformed and analyzed as a split plot with treatments as whole plots and time as a subplot. Treatments were in a randomized complete block design with three replicates. The time $\times$ adjuvant inter-
Table 3. Retention of bifenthrin + adjuvant mixtures on the upper surfaces of cotton leaves as determined with immersion cell apparatus.

\begin{tabular}{|c|c|c|}
\hline Treatment & $\begin{array}{l}\text { Adjuvant } \\
\text { formulation }\end{array}$ & Retention \\
\hline & $\%$ & $\mu \mathbf{L} \mathrm{cm}^{-2}$ \\
\hline Orchex 796 & 100 & $58.7 \mathbf{a}\rceil$ \\
\hline Agri-Dex & 2.0 & $29.4 \mathrm{~b}$ \\
\hline Soy-Dex & 1.0 & $27.5 b c$ \\
\hline Standard (Capture) & - & $24.8 \mathrm{~cd}$ \\
\hline Silwet 77 & 0.18 & $24.8 \mathrm{cde}$ \\
\hline Dyne-Amic & 0.65 & $24.8 \mathrm{cde}$ \\
\hline Agrimax-3 & 0.25 & $24.8 \mathrm{cde}$ \\
\hline$X-77$ & 0.25 & 24.8de \\
\hline Kinetic & 0.25 & 23.9de \\
\hline Intac & 1.56 & 23.9de \\
\hline Plyac & 0.25 & $23.9 \mathrm{de}$ \\
\hline Penetrator Plus & 0.25 & $22.9 \mathrm{de}$ \\
\hline Agrimax-3H & 0.25 & $22.9 d e$ \\
\hline Bond & 0.25 & $22.0 \mathrm{e}$ \\
\hline
\end{tabular}

$\uparrow$ Means followed by the same letter are not significantly different $(P<$ 0.05) as determined by PDIFF (SAS Instifute, 1990).

action was significant in all tests in initial analyses; therefore, separate ANOVAs were conducted on data for each time period.

Data from the retention test were analyzed as a completely random design. Data from each bioassay were analyzed as a randomized complete block design. All data were subjected to an ANOVA using SAS's PROC MIXED (Littell et al., 1996). Least square means were separated using the PDIFF option.

\section{RESULTS AND DISCUSSION} Rainfastness Test

The overall results of these tests indicate that retention of bifenthrin on the leaf after rainfall increased with the amount of time that the insecticide + adjuvant mixtures were on the leaf before rainfall occurred.

In Test 1 , Bond significantly increased the percentage of bifenthrin retained on the leaf surface after simulated rainfall at $0.25 \mathrm{~h}\left(F_{4,8}=69.97 ; P>F=0.0001\right)$ and at $1.0 \mathrm{~h}$ after treatment $\left(F_{4,10}=28.10 ; P>F=0.0001\right)$ above that of the bifenthrin-alone (control) treatment (Table 2). Bond retained only about $47 \%$ of bifenthrin on the leaf surface compared with $24 \%$ in the bifenthrinalone (control) treatment. Silwet 77 significantly decreased the rainfastness of bifenthrin below that of the control at $0.25 \mathrm{~h}$ after treatment, while X-77 decreased rainfastness at both 0.25 and $1.0 \mathrm{~h}$ after treatment.

In Test 2, Kinetic significantly decreased $\left(F_{3,8}=5.88\right.$; $P>F=0.0202$ ) the retention of bifenthrin below that of the bifenthrin control when rainfall occurred at $0.25 \mathrm{~h}$ after treatment. When rainfall occurred $1.0 \mathrm{~h}$ after treatment, none of the adjuvants in this test had higher $\left(F_{3,6}=\right.$ $5.74, P=0.0338)$ retention than the control. At $4.0 \mathrm{~h}$ after treatment, there were no significant differences in retention among the treatments.

In Test 3, mixing Plyac with bifenthrin increased retention of the insecticide above that of the bifenthrinalone control when rainfall occurred at $0.25 \mathrm{~h}\left(F_{4,8}=\right.$ $4.8 ; P>F=0.0003)$ and at $4.0 \mathrm{~h}\left(F_{4,0}=11.74 ; P>\right.$ $F=0.0009)$ after treatment. However, at $1.0 \mathrm{~h}$ after treatment, all treatments had lower retention than the 
control. Agri-Dex and Dyne-Amic had significantly lower retention than the control at all rainfall intervals, which indicates that these adjuvants increased the susceptibility of bifenthrin to runoff from rainfall.

Only Bond and Plyac showed any rainfastening activity. Bond contains $45 \%$ synthetic latex and $10 \%$ oxyalylated alcohol, while Plyac is a blend of emulsifiable oxidized polyethylene and ethoxylated phenoxy alcohol at $27.5 \%$ of the mixture (Harvey, 1993). The rest of the adjuvants resulted in little retention of bifenthrin on the leaf and, in some cases, actually made the insecticide more prone to being washed off.

\section{Retention Test}

Only two adjuvants, Orchex 796 and Agri-Dex, resulted in significantly higher $(F=78.73, P>F=0.0001)$ retention than the standard of bifenthrin mixed with water (Table 3). Twice as much Orchex 796 was retained on the plant as the next best treatment. Orchex 796 is a paraffinic oil with low surface tension (29.2 dynes $\mathrm{cm}^{-1}$ ) that increases cuticular coverage over the leaf, binding the insecticide to the leaf surface (Chambers, 1996). Orchex 796 also penetrates into leaf microcavities and leaf wax (Chambers et al., 1992). Bond, which has a latex composition, was the only adjuvant to have significantly lower retention than the bifenthin standard. However, Bond was one of two adjuvants to have greater rainfastness than the bifenthrin standard.

\section{Bioassay}

Bond did not interfere with the uptake of bifenthrin, a contact insecticide, by tobacco budworm larvae. Percentage mortality of tobacco budworm larvae exposed to cotton leaves treated with bifenthrin + Bond $(70.0 \pm$ $5.8 \%)$ was not significantly different $(F=1.0, P>F=$ $0.37)$ from that of larvae exposed to leaves treated with bifenthrin alone $(76.7 \pm 3.3 \%)$.

Likewise, Bond did not have any antifeedant or repellant effects when mixed with a $B$. thuringiensis formulation. In a bioassay designed to demonstrate effects of Bond on feeding activity, soybean looper larvae feeding on soybean leaves treated with a mixture of $B$. thuringiensis + Bond had $92.5 \pm 4.8 \%$ mortality compared with $83.8 \pm 6.6 \%$ mortality of larvae feeding on soybean leaves treated with the $B$. thuringiensis formulation alone. These results indicate that Bond's rainfastening attributes did not interfere with the performance of a contact or stomach insecticide.

\section{CONCLUSIONS}

Increasing plant coverage during insecticide application through the use of adjuvants classed as spreaders and wetters may enhance efficacy by increasing the probability that an insect will encounter the insecticide residue. The results of this research indicate that spreaders can improve retention of insecticides on the plant during the application process but that spreaders may make the insecticide more prone to washoff during rainfall. Application of insecticides during the hot and humid conditions of the summer months in the mid-south is always a gamble because these conditions are favorable for the rapid development of thunderstorms. Yet, this is the time of the year when insect pests are most abundant. Using adjuvant stickers can provide a hedge against the complete loss of insecticide during rainfall.

\section{ACKNOWLEDGMENTS}

Debra Gary, Ben Naron, and Darion Gibson, Application and Production Technology Research Unit, assisted in this research. Debbie Boykin provided guidance for the analysis of data.

\section{REFERENCES}

Bryson, C.T. 1987. Effects of rainfall on foliar herbicides applied to rhizome johnsongrass. Weed Sci. 35:115-119.

Carlton, J.B. 1992. Simple téchniques for measuring spray deposits in the field. II. Dual side leaf washer. ASAE Paper no. 921618. ASAE, St. Joseph, MI.

Carlton, J.B. 1996. Retention phenomenon from saturating plant leaves with agricultural liquids. Trans. ASAE 39:393-398.

Chambers, G.V.1996. The role of Orchex 796 in pesticide applications. p. 67-87. In H.M. Collins, F.R. Hall, and M. Hopkins (ed.) Pesticide formulations and application systems. 15th vol. ASTM STP 1268. American Society for Testing and Materials, Philadelphia, PA.

Chambers, G.V., M.C. Bulawa, C.G. McWhorter, and J.E. Hanks. 1992. Use of surface relationship models to predict the spreading of nonaqueous droplets on johnsongrass. p. 218-246. In L.E. Bode and D.G. Chasin (ed.) Pesticide formulations and application systems. 11th vol. ASTM STP 1112. American Society for Testing and Materials, Philadelphia, PA.

Foy, C.L. 1993. Progress and developments in adjuvant use since 1989 in the USA. Pestic. Sci. 38:65-76.

Harvey, L.T. 1993. A guide to agricultural spray adjuvants used in the United States. Thompson Publ., Fresno, CA.

Littell, R.C., G.A. Milliken, W.W. Stroup, and R.D. Wolfinger. 1996. SAS system for mixed models. SAS Inst., Cary, NC.

McDowell, L.L., G.H. Willis, L.M. Southwick, and S. Smith. 1984. Methyl parathion and EPN wash-off from cotton plants by simulated rainfall. Environ. Sci. Technol. 18:423-427.

McDowell, L.L., G.H. Willis, L.M. Southwick, and S. Smith. 1987. Fenvalerate wash-off from cottton plants by rainfall. Pestic. Sci. 21:83-92.

Pick, F.E., L.P. van Dyk, and P.R. De Beer. 1984. The effect of simulated rain on deposits of some cotton pesticides. Pestic. Sci. 15:616-623.

SAS Institute. 1990. SAS user's guide. SAS Inst., Cary, NC.

Willis, G.H., L.L. McDowell, S. Smith, and L.M. Southwick. 1986. Permethrin wash-off from cotton plants by simulated rainfall. J. Environ. Qual. 15:116-120.

Willis, G.H., L.L. McDowell, S. Smith, and L.M. Southwick. 1988 Rainfall amount and intensity effects on carbaryl wash-off from cotton plants. Trans. ASAE 31:86-90. 